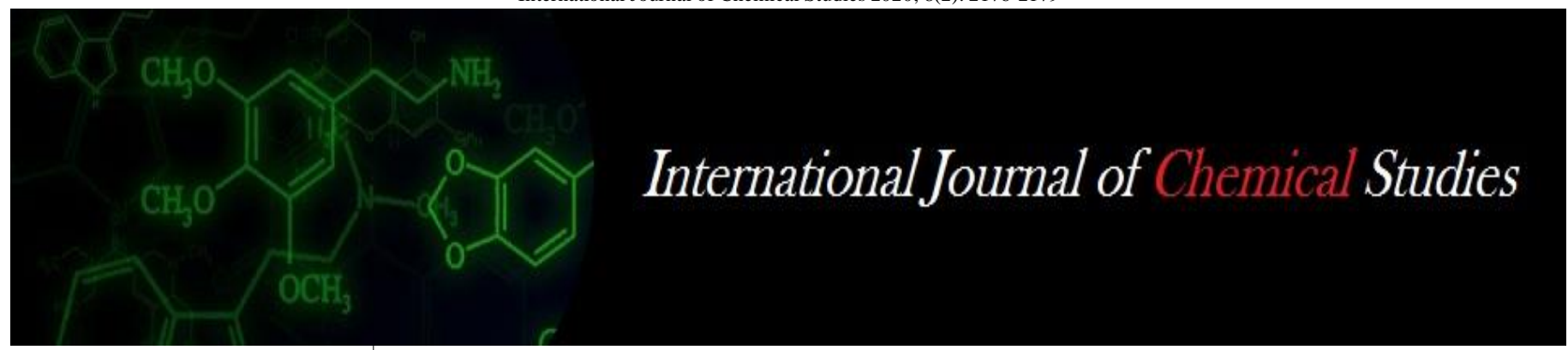

P-ISSN: 2349-8528

E-ISSN: 2321-4902

www.chemijournal.com

IJCS 2020; 8(2): 2176-2179

(C) 2020 IJCS

Received: 07-01-2020

Accepted: 09-02-2020

Nithyashree K

Ph.D. Scholar, Department of

Food Science and Nutrition,

G.K.V.K, UAS, Bangalore,

Karnataka, India

Geetha K

Professor and Scheme Head,

AICRP Home Science (Food and

Nutrition), G.K.V.K, UAS,

Bangalore, Karnataka, India

Deepa J

Ph.D. Scholar, Department of

Food Science and Nutrition,

G.K.V.K, UAS, Bangalore,

Karnataka, India

\section{Physico-chemical and functional characteristics of rice and wheat}

\section{Nithyashree K, Geetha K and Deepa J}

DOI: https://doi.org/10.22271/chemi.2020.v8.i2ag.9072

\begin{abstract}
Rice and wheat are considered as staple food in many parts of the world where it is consumed regularly as the main source of calories and to meet the nutritional needs of millions of people every day. The aim of the study was to investigate the physical properties, proximate composition and dietary fibre content in rice and wheat. The physical properties of grains are necessary for effective design of equipment to handle, transport, processing and storage of crop. The physical characteristics such as 1000 seeds weight, 1000 seeds volume, hydration capacity, hydration index, swelling capacity, swelling index, specific gravity and bulk density of the rice and wheat samples were considerably different from each other. The results of proximate composition showed that moisture content of rice and wheat was 8.9 and 8.7 per cent respectively. Wheat had highest protein content $(10.70 \mathrm{~g} / 100 \mathrm{~g})$ compared to rice $(6.7 \mathrm{~g} / 100 \mathrm{~g})$. The fat content in rice and wheat were 0.50 and $2.0 \mathrm{~g} / 100 \mathrm{~g}$ respectively. The total ash content in rice was $0.50 \mathrm{~g} / 100 \mathrm{~g}$ and in wheat $1.4 \mathrm{~g} / 100 \mathrm{~g}$. Rice had highest energy and carbohydrate content when compared to wheat. The total dietary fibre content was highest in wheat sample i.e. $12.34 \mathrm{~g} / 100 \mathrm{~g}$ compared to rice $(2.19 \mathrm{~g} / 100 \mathrm{~g})$. Genetic variation and agro climatic condition may be the reason for the difference recorded.
\end{abstract}

Keywords: Physical properties, nutrients, dietary fibre

\section{Introduction}

Cereals play a vital role in human diet as an important source of energy, protein and micronutrients. Dietary recommendations worldwide emphasize the significance of cereals in a balanced diet. Furthermore, cereals have been proven to provide additional health benefits while satisfying the energy and nutritional needs of humans. Risk of non-communicable diseases (NCDs) is increasing worldwide at an alarming rate in developed as well as developing regions. Several studies found that the regular consumption of whole grains and wholegrain products are helpful to prevent and to reduce the prevalence of NCDs Okarter and Liu (2010) ${ }^{[16]}$ and Slavin (2004) ${ }^{[18] .}$

Rice (Oryza sativa L.) is a major dietary component of people in most of the countries. It is highly consumed in Asia and Africa and less in the European Union (Vlachos and Arvanitoyannis, 2008) [21]. Rice is rich in starch, which is composed of amylose and amylopectin. The rice grain constitutes $12 \%$ water, $75 \%-80 \%$ starch and only $7 \%$ protein with a full complement of amino acids. Its protein is highly digestible (93\%) with excellent biological value $(74 \%)$ and protein efficiency ratio $(2.02 \%-2.04 \%)$ owing to the presence of higher concentration (about 4\%) of lysine Eggum (1969) ${ }^{[8]}$; Eggum (1973) ${ }^{[9]}$; Bressani, (1971) ${ }^{[10]}$ and Juliano (1993) ${ }^{[11]}$. Rice is the foremost cereal food crop in many developing countries. About half of the world population consumes rice as their major source of carbohydrate. Almost $95 \%$ of the rice production is recorded in Asian countries (Bhattacharjee et al., 2002) ${ }^{[5]}$.

The common wheat (Triticum aestivum L.) is an important component of the human diet, and is used in the production of many food products, including bread, noodles, steamed bread, and cakes, providing energy based on the high contents of protein and carbohydrate. Wheat products contain high levels of antioxidants, which confer protection against cancer and heart diseases mostly coming from phenolics, Adom (2005) ${ }^{[1]}$ and Ward (2008) ${ }^{[22]}$. Wheat is an important agricultural commodity and a main food all around the world. It is one of the major
Corresponding Author: Nithyashree K

Ph.D. Scholar, Department of Food Science and Nutrition, G.K.V.K, UAS, Bangalore, Karnataka, India 
food grains consumed by people (Van hung et al., 2009) ${ }^{[20]}$. It contains important beneficial components for human nutrition. Due to the high content of natural antioxidants, wheat and wheat-based products can perfectly serve as a basis for the functional foods, development designed to improve the health of millions of consumers (Vaher et al., 2010) ${ }^{[19]}$. Although wheat is used mainly as a source of energy, whole wheat grains are an excellent source of dietary fibre, vitamins, minerals and other bioactive phytochemicals such as antioxidant compounds (Cai et al., 2014) ${ }^{[7]}$. For this reason, numerous studies have been conducted to investigate the nutritional quality and health benefits of whole wheat grains. This study investigates the some physical and functional properties, proximate composition and dietary fibre content in rice and wheat.

\section{Materials and methods}

Rice and wheat grain samples were purchased from local market at Bangalore (India). The grains were cleaned from foreign particles and debris. The grain were ground directly using stone mill and passed through 60 mesh sieve to obtain fine flour. All the reagents used in the study were of analytical grade.

\section{Estimation of physical and functional properties}

Thousand seeds weight of the grains was measured by the method (Balasubramanian and Vishwanathan et al., 2010) ${ }^{[4]}$.

Thousand seed volume, swelling capacity, swelling index, hydration capacity, hydration index and specific gravity were measured by the method (William et al., 1983) ${ }^{[23]}$.

The bulk density was calculated as follows

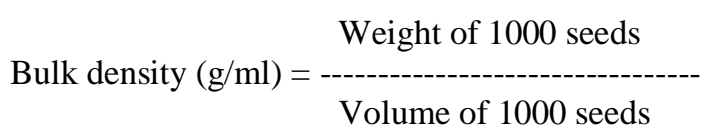

Estimation of proximate composition
By using the standard methods, all the samples moisture, ash, crude fat, crude fibre, crude protein and carbohydrate contents of each food sample were analysed and all of which were carried out in triplicate. Moisture content was determined by heating $5.0 \mathrm{~g}$ of each sample to a constant weight in a crucible placed in a hot air oven maintained at $105^{\circ} \mathrm{C}$. The ash content was determined by incineration of $5.0 \mathrm{~g}$ samples placed in muffle furnace maintained at $550^{\circ} \mathrm{C}$ for $5-8$ hours. The crude fibre was obtained by digesting $2.0 \mathrm{~g}$ of the samples with $\mathrm{H}_{2} \mathrm{SO}_{4}$ and $\mathrm{NaOH}$ and incinerating the residue in a muffle furnace maintained at $550^{\circ} \mathrm{C}$ for $5-8$ hours. The crude protein $(\%$ total nitrogen $\times 6.25)$ was determined by Kjeldhal method using $2.0 \mathrm{~g}$ of the samples. The carbohydrate content was determined by the difference i.e. deducing the sum of the percentage (moisture, ash, fibre, fat and protein) from 100 using standard technique (AOAC, 1980) ${ }^{[2]}$.

\section{Estimation of energy}

Calorific value is an important property indicating the useful energy content of foods. The gross food energy was estimated by using the equation (AOAC, 1980) ${ }^{[2]}$.

Energy $($ Kcal $)=[$ Protein $(\mathrm{g}) \times 4]+[$ Carbohydrate $(\mathrm{g}) \times 4]+$ [Fat $(\mathrm{g}) \times 9$ ]

\section{Estimation of dietary fibre}

Dietary fibre and its components including soluble and insoluble were analysed. Initially, insoluble and soluble fibres were estimated then total dietary fibre was calculated by using the formula (AOAC, 1980) ${ }^{[2]}$.

\section{Insoluble dietary fibre}

Defatted foods were gelatinized; proteins and starch were removed by enzymatic digestion. The residue was quantified gravimetrically.

Insoluble dietary fibre $($ IDF $)=$ IDF residue $-($ Protein + Ash)

$$
\begin{aligned}
& \text { Weight of the IDFR }(\mathrm{g})-\{\text { Protein }(\mathrm{g}) \text { in IDFR+ Ash }(\mathrm{g}) \text { in IDFR }\} \\
& \text { Weight of the sample }(\mathrm{g})
\end{aligned}
$$

IDFR = Insoluble dietary fibre residue

\section{Soluble dietary fibre}

The soluble fibre is estimated in the filtrate obtained after enzymatic digestion of protein and carbohydrate of defatted food. The soluble fibre is precipitated and estimated gravimetrically.

Soluble dietary fibre $($ SDF $)=$ Weight of SDF residue $($ Protein + Ash)

$$
\begin{gathered}
\text { Weight of the SDFR }(\mathrm{g})-\{\text { Protein }(\mathrm{g}) \text { in SDFR+ Ash }(\mathrm{g}) \text { in SDFR }\} \\
\text { WDF } \%=- \text { Weight of the sample }(\mathrm{g})
\end{gathered}
$$

SDFR $=$ Soluble dietary fibre residue

\section{Estimation of total dietary fibre}

The total dietary fibre was the sum of soluble and insoluble dietary fibre.

Total dietary fibre $=\mathrm{IDF}+\mathrm{SDF}$

\section{Statistical analysis}

The data reported in all of the tables are the averages of triplicate observations. Mean values were calculated and compared at different significance level. Significance of differences between treatment mean values for each trait was tested by using Duncan's multiple range tests.

\section{Results and discussion}

The physical and functional properties of rice and wheat samples are presented in Table 1. The highest 1000 seeds weight and seed volume was observed in wheat compared to rice. The 1000 grains weight of wheat was higher than that reported by Karimi et al. (2009) ${ }^{[13]}$ and that of rice were lower than that reported by Raghuvanshi et al. (2017) ${ }^{[17]}$. The difference observed in the study may be due to difference in varieties and also due to agro climatic condition grown. The wheat having the highest hydration capacity $(22.77 \mathrm{~g} / 100 \mathrm{~g})$, hydration index (0.50), swelling capacity and swelling index compared to rice. The difference in hydration capacity, hydration index, swelling capacity and swelling index in the 
present study may be due to varietal difference, grain size and seed volume. The rice having highest bulk density $0.90 \mathrm{~g} / \mathrm{ml}$ compared to wheat $0.86 \mathrm{~g} / \mathrm{ml}$.

Table 1: Physical characteristics and functional properties of rice and wheat

\begin{tabular}{|c|c|c|c|}
\hline Parameters & Rice & Wheat & t test \\
\hline 1000 seeds weight $(\mathrm{g})$ & 10.62 & 45.13 & $67.48^{*}$ \\
\hline 1000 seeds volume $(\mathrm{ml})$ & 11.77 & 52.53 & $86.73^{*}$ \\
\hline Hydration capacity $(\mathrm{g})$ & 2.06 & 22.77 & $45.94^{*}$ \\
\hline Hydration index & 0.19 & 0.50 & $17.84^{*}$ \\
\hline Swelling capacity $(\mathrm{g})$ & 4.90 & 40.33 & $55.71^{*}$ \\
\hline Swelling index & 0.41 & 0.77 & $18.73^{*}$ \\
\hline Specific gravity & 1.12 & 1.38 & $1.30^{*}$ \\
\hline Bulk density $(\mathrm{g} / \mathrm{ml})$ & 0.90 & 0.86 & $15.30^{*}$ \\
\hline
\end{tabular}

* Significant at $p<0.05$ level

The nutrient compositions of rice and wheat samples were presented in Table 2. Moisture content is the one of the most critical physiological factors in flourishing grain storage of the food grain. High moisture content leads to the increased susceptibility towards the storage spoilage due to the fungal and insect problems, respiration and germination. The moisture content of rice and wheat was 8.9 and 8.7 per cent respectively. The protein being one of the most important nutrients should be supplied through diet in an adequate amount (Arora et al., 2003) ${ }^{\text {[3] }}$. Therefore, it is essential to assess the protein content in the available food grain sources to meet the protein requirement of the body. Wheat had highest protein content $(10.70 \mathrm{~g} / 100 \mathrm{~g})$ compared to rice $(6.7 \mathrm{~g} / 100 \mathrm{~g})$. The differences for the protein content observed in the present study may be due to the veritable difference and agro-climatic conditions grown. Fat in the diet is required for absorption and utilisation of fat-soluble vitamin's like vitamin A and carotene present in the diet (Murthy et al., 1996) ${ }^{[15]}$. The fat content in rice and wheat were 0.50 and $2.0 \mathrm{~g} / 100 \mathrm{~g}$ respectively. The total ash content in rice was $0.50 \mathrm{~g} / 100 \mathrm{~g}$ and in wheat $1.4 \mathrm{~g} / 100 \mathrm{~g}$. Large diversity in ash content among the grains is due to the difference in mineral accumulation in food grains. It might also be due to the different efficiency of translocation of minerals from root tissues to edible plant organs and accumulation of the elements in edible portions (Manimozhi et al., 2015) ${ }^{[14]}$. Even growing environment and genetic differences also influence the accumulation of minerals in food grains (Kamatar et al., 2015) ${ }^{[12]}$. The crude fibre content was observed in rice and wheat was 0.30 and 1.3 $\mathrm{g}$ respectively. Rice had highest energy and carbohydrate content when compared to wheat. Genetic variation and agro climatic condition may be the reason for the difference recorded.

Table 2: Proximate composition of rice and wheat

\begin{tabular}{|c|c|c|c|}
\hline Parameters & Rice & Wheat & t test \\
\hline Moisture (\%) & 8.9 & 8.7 & $1.5^{\mathrm{NS}}$ \\
\hline Protein $(\mathrm{g})$ & 6.7 & 10.7 & $16.5^{*}$ \\
\hline Fat $(\mathrm{g})$ & 0.5 & 2.0 & $10.8^{*}$ \\
\hline Total ash $(\mathrm{g})$ & 0.5 & 1.4 & $13.2^{*}$ \\
\hline Crude fibre $(\mathrm{g})$ & 0.3 & 1.3 & $17.8^{*}$ \\
\hline Carbohydrates $(\mathrm{g})$ & 83.1 & 75.6 & $21.0^{*}$ \\
\hline Energy (Kcal) & 363 & 360 & $1.76^{*}$ \\
\hline
\end{tabular}

* Significant at $p<0.05$ level NS- Non significant

The total dietary fibre, soluble and insoluble dietary fibre contents of rice and wheat samples were depicted in Table 3. Dietary fibre is the plant material in the diet which is resistant to enzymatic digestion which includes cellulose, noncellulosic polysaccharides such as hemicelluloses, pectic substances, gums, mucilage's and a non-carbohydrate component called lignin. Dietary fibre which is present as soluble and insoluble form is proved to play an important role in the management of metabolic disorders like diabetes mellitus, hyperlipidemia, improved bowel motility and in turn reduce the incidence of colon cancer. Millets in general are rich in dietary fibre content (9 to 15\%). In the present investigation, total dietary fibre content was highest in wheat sample i.e. $12.34 \mathrm{~g} / 100$ compared to rice $(2.19 \mathrm{~g} / 100 \mathrm{~g})$.

Table 3: Dietary fibre content in rice and wheat

\begin{tabular}{|c|c|c|c|}
\hline Parameters & Rice & Wheat & t test \\
\hline Total dietary fibre $(\mathrm{g})$ & 2.19 & 12.34 & $47.50^{*}$ \\
\hline Soluble fibre $(\mathrm{g})$ & 0.77 & 2.43 & $50.51^{*}$ \\
\hline Insoluble fibre $(\mathrm{g})$ & 1.38 & 9.80 & $29.10^{*}$ \\
\hline
\end{tabular}

\section{Conclusion}

The paper concludes with information on physical properties of rice and which may be useful for optimizing milling operations, designing the storage structures and machinery, which will help to avoid the postharvest and milling losses. Cereals are the staple food for millions of people Africa and Asia. They are rich in carbohydrate and energy content, making them useful components of dietary and nutritional balance in foods. The dietary fibre has some important role in inhibiting cholesterol synthesis.

\section{References}

1. Adom KK, Sorrells ME, Liu RH. Phytochemicals and antioxidant activity of milled fractions of different wheat varieties. Journal of Agricultural and Food Chemistry. 2005; 53:2297-2306.

2. AOAC. Official methods of analysis. Association of official analytical chemists. washington. DC. 1980; 13th edition.

3. Arora P, Seghal SN, Kawatra A. Effect of dry heating on total minerals and their $\mathrm{HCl}$ extractability in pearl millet. Recommended Trends Millet Proceedings Utilization. 2003; 64:28-31.

4. Balasubramanian S, Vishwanathan R. Influence of moisture content on physical properties of minor millets. Journal of Food Science and Technology. 2010; 47(3):279-284.

5. Bhattacharjee P, Singhal RS, Kulkarni PR. Basmati rice: A review. International Journal of Food Science \& Technology. 2002; 37(1):1-12. http://dx.doi.org/10.1046/j.1365-2621.2002.00541.x.

6. Bressani R, Elias LG, Juliano BO. Evaluation of protein quality. Journal of Agricultural and Food Chemistry. 1971; 19:1028-1036.

7. Cai L, Choi I, Lee CK, Park KK, Baik BK. Bran characteristics and bread-baking quality of whole grain wheat flour. In Cereal Chemistry. 2014; 91(4):398-405. DOI: 10.1094/CCHEM-09-13-0198-R.

8. Eggum BO. Evaluation of protein quality and the development of screening techniques. In: New Approaches to Breeding for Improved Plant Protein. Vienna, IAEA, 1969, 125-135.

9. Eggum BO. A study of certain factors influencing protein utilization in rats and pigs. Publ. 406. Copenhagen, Agricultural Research Laboratory, 1973, 173. 
10. Eggum BO, Nutritional aspects of cereal protein. In: Genetic diversity in Plants. New York, USA: Plenum Press, 1977, 349-369.

11. Juliano BO, Nutritional value of rice and rice diets. In: Rice in Human Nutrition. IRRI and FAO, Rome, Italy, 1993, 61-84.

12. Kamatar B, Sumesh KB, Ravi SN. Growth dynamics and mineral composition of foxtail millet production in India. Economic Affairs. 2015; 11(2):198-206.

13. Karimi M, Kheiralipour K, Tabatabaeefar A, Khoubakht GM, Naderi M, Heidarbeigi K. The effect of moisture content on physical properties of wheat. Pakistan Journal of Nutrition. 2009; 8(1):90-95.

14. Manimozhi S, Nirmalakumari A, Senthil J. Genetic diversity for zinc, calcium and iron content of selected little millet genotype. Journal of Nutrition and Food Sciences. 2015; 5:6-10.

15. Murthy NK, Chitra A, Parvathamma R. Quality and storage stability of crude palm oil and its blends. Indian Journal of Nutrition and Dietetics. 1996; 32:238-249.

16. Okarter N, Liu RH. Health benefits of whole grain phytochemicals. Critical Reviews in Food Science and Nutrition. 2010; 50:193-208.

17. Raghuvanshi SR, Dutta A, Tewari G, Suri S. Qualitative characteristics of red rice and white rice procured from local marke of uttarakhand: A comparative study. Journal of Rice Research. 2017; 10(1):49-53.

18. Slavin J. Whole grains and human health. Nutrition Research Reviews, 2004; 17:99-11.

19. Vaher M, Matso K, Levandi T, Helmja K, Kaljurand M. Phenolic compounds and the antioxidant activity of the bran, flour and whole grain of different wheat varieties. In Procedia Chemistry, 2010; 2(1):76-82. DOI: $10.1016 /$ j.proche.2009.12.013.

20. Van Hung P, Maeda T, Miyatake K, Morita N. Total phenolic compounds and antioxidant capacity of wheat graded flours by polishing method. In Food Research International. 2009; 42(1):185-190.

DOI: 0.1016/j.foodres.2008.10.005.

21. Vlachos A, Arvanitoyannis IS. A review of rice authenticity/ adulteration methods and results. Critical Reviews in Food Science and Nutrition. 2008; 48:553598.

22. Ward JL, Poutanen K, Gebruers K, Piironen V, Lampi AM, Nystrom L et al. The health grain cereal diversity screen: concept, results and prospects. Journal of Agricultural and Food Chemistry. 2008; 56:9699-9709.

23. William PC, Nakoul H, Singh KB. Relationship between time and some physical characteristics in chickpeas (Cicer arietinum L.). Journal of the Science of Food and Agriculture. 1983; 34:492-496. 